\title{
Dynamic Response of the Vegetation Carbon Storage in the Sanjiang Plain to Changes in Land Use/cover and Climate
}

\section{Haiyan Li ( $\sim$ lihaiyan19740902@163.com)}

Heilongjiang Academy of Sciences Institute of Natural Resources and Ecology https://orcid.org/00000001-9459-3828

\section{Yi Qu}

Heilongjiang Academy of Sciences Institute of Natural Resources and Ecology

\section{Xingyu Zeng}

Heilongjiang Academy of Sciences Institute of Natural Resources and Ecology

\section{Hongqiang Zhang}

Heilongjiang Academy of Sciences Institute of Natural Resources and Ecology

\section{Ling Cui}

Heilongjiang Academy of Sciences Institute of Natural Resources and Ecology

\section{Chunyu Luo}

Heilongjiang Academy of Sciences Institute of Natural Resources and Ecology https://orcid.org/00000002-6191-387X

\section{Research Article}

Keywords: Sanjiang Plain, Vegetation carbon storage, Land Use/Cover Change, Climate Change, Pixelbased correlation analysis

Posted Date: May 5th, 2021

DOI: https://doi.org/10.21203/rs.3.rs-482224/v1

License: (c) (1) This work is licensed under a Creative Commons Attribution 4.0 International License. Read Full License 


\title{
Dynamic Response of the Vegetation Carbon Storage in the
}

\section{Sanjiang Plain to Changes in Land Use/Cover and Climate}

\author{
Haiyan Li, Yi Qu, Xingyu Zeng, Hongqiang Zhang, Ling Cui, Chunyu Luo*
}

\begin{abstract}
Large-scale human activities especially the destruction of forest land, grassland, and unused land result in a large amount of carbon release into the atmosphere and cause drastic changes in land use/cover in the Sanjiang Plain. As a climate change-sensitive and ecologically vulnerable area, the Sanjiang Plain ecosystem's carbon cycle is affected by significant climate change. Therefore, studying the impact of the changes in land use/cover and climate on the carbon storage of the vegetation in the Sanjiang Plain is important. The dynamic impact of the changes in land use/cover and climate on the vegetation carbon storage was analyzed using Remote Sensing (RS), Geographic Information System (GIS) technology, and mathematical statistics and taking Landsat-TM/OLI and MODIS Normal Difference Vegetation Index (NDVI) remote sensing data, temperature, and precipitation as main data sources. Research results showed the following observations. From 2001 to 2015, the vegetation carbon storage in the Sanjiang Plain continued to increase (total increase $=97.65 \mathrm{Tg}$ ). . The carbon storage of the forest land increased by 98.73 $\mathrm{Tg}$, and the carbon storage of cultivated land increased by $0.56 \mathrm{Tg}$. The carbon storage values of grassland and unused land decreased to 0.86 and $0.78 \mathrm{Tg}$, respectively. The increase in the carbon storage of cultivated land was caused by the increased area, and that of forest land was attributed to the increased carbon density. The decrease in the carbon storage of grassland and unused land was out of the decrease in its area. Therefore, the transform in land use types and vegetation carbon density changed the vegetation carbon storage. Through the pixel-by-pixel analysis of the invariant region, the carbon storage of various vegetations in the Sanjiang Plain was negatively correlated with the average temperature and positively correlated with the average precipitation. The partial correlation analysis of the changes in climate and land use/cover concluded that the changes in land use/cover and vegetation carbon density in the Sanjiang Plain were the main controlling factors for the changes in the vegetation carbon storage.
\end{abstract}

Keywords: Sanjiang Plain,Vegetation carbon storage,Land Use/Cover Change,Climate Change,Pixel-based correlation analysis

\footnotetext{
*Correspondence :iamluo2002@163.com

Harbin Base of International Centre on Space Technologies for Natural and Cultural Heritage under the Auspices of UNESCO(HIST-HB), National and Local Joint laboratory of Wetland and Ecological Consernation, Institute of Natural Resources and Ecology, Heilongjiang Academy of Sciences,Harbin, 150040,China.

Full list of author information is available at the end of the article
} 


\section{Introduction}

The terrestrial ecosystem is one of the important carbon pools and an important link in the interaction between human activities and climate change[1,2]. Vegetation is the main body of the terrestrial ecosystem [3] and plays an extremely important role in the global carbon cycle. The scientific and timely evaluation of the response of the vegetation carbon storage to human activities and climate change is a hotspot in current climate change and regional sustainable development research[4-7]. In recent years, scholars have focused on the impact of land use/cover on the vegetation carbon storage. De Jong[8] believes that land use/cover has changed the ecosystem carbon density in Chiapas. Martens[9] has concluded that the carbon storage of the forest land in the U.S. is $29 \%$ and $46 \%$ higher than that of the local grassland and cultivated land, respectively. Erb[10] has quantitatively studied the impact of human activities in Australia on the carbon storage of surface vegetation. Erb[10] has concluded that the conversion of forest land into cultivated land, grassland, and urban land reduces the vegetation carbon storage by $77 \%$ and that the decrease in forest age and the change in tree species decrease the forest carbon storage by $30 \%$. The achievements of Hutyra[11] in studying the effect of the vegetation cover change on the carbon storage contribute to the evaluation and the analysis of urban carbon sequestration potential. Fang et al. [12,13] and Li et al.[14] have estimated the carbon storage of China's terrestrial vegetation. Zhang et al.[15], Wu et al.[16], Kong et al.[17], and Wei et al. [18] have assessed the effects of land use/cover change on the vegetation carbon in different regions of China. However, studies on the spatiotemporal changes of the vegetation carbon storage involving the combined effects of regional land use/cover change and climate change are few, and this field needs improvement and breakthroughs in the future. 
The reclamation of the Sanjiang Plain in a large area since the middle and late 20th century has resulted in drastic land use/cover changes. A large number of forest lands, wetlands, and grasslands have been reclaimed into cultivated land, thereby reducing the productivity of vegetation and the input of soil organic matter and leading to the release of large amounts of carbon elements into the atmosphere [19]. The research on the effects of land use/cover change processes and regional climate changes on the ecosystem carbon storage due to human activities in this area can provide a theoretical basis for global change research and offers a reference for revealing the process and law of human land and climate system change in typical sensitive areas [20]. This paper has explored the dynamic effects of the changes in land use/cover and climate on the vegetation carbon storage in the Sanjiang Plain by taking remote sensing images and meteorological data as the main data sources and using GIS technology and mathematical statistics. Research results are important to regulate the human land use behavior in the region and mitigate and adapt to climate change.

\section{General situation}

The Sanjiang Plain is located in the northeast of Heilongjiang Province, China and formed by the impact of Heilongjiang, Songhua, and Wusuli Rivers. Its geographical coordinates are

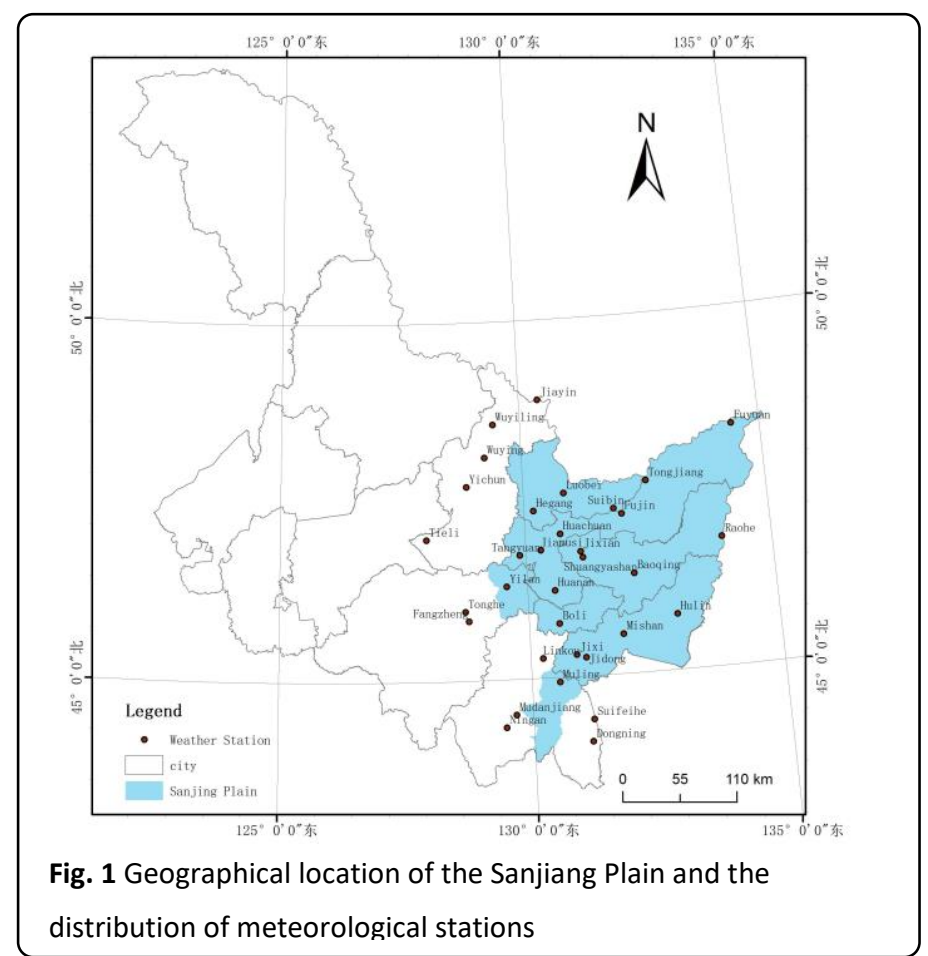
$43^{\circ} 49^{\prime} 55^{\prime \prime}-48^{\circ} 27^{\prime} 40^{\prime \prime} \mathrm{N}$ and $129^{\circ} 11^{\prime} 20^{\prime \prime}-135^{\circ} 05^{\prime} 26^{\prime \prime} \mathrm{E}$. The Sanjiang Plain has a total area of about 
$108900 \mathrm{~km}^{2}$ and is the largest and most concentrated wetland in China. Moreover, the Sanjiang Plain is one of the most critical areas for wetland and biodiversity conservation in the world and an important food production and reserve base in China. This area has four distinct seasons with long freezing period, annual average temperature of $1.6{ }^{\circ} \mathrm{C}-3.9^{\circ} \mathrm{C}$, and annual precipitation of $500-700 \mathrm{~mm}$ that is concentrated in summer and autumn, and humid and semihumid continental monsoon climate. The distribution of the study area is shown in Fig. 1.

\section{Data sources and treatment}

Landsat-TM/OLI, MODIS NDVI and meteorological data were the main data sources. The time span was 2001-2015 and divided into four periods: 2001, 2005, 2010, and 2015. The Landsat-TM/OLI remote sensing image was obtained from the international scientific data service platform(http://www.cnic.cas.cn/) with a resolution of $30 \mathrm{~m}$. The original remote sensing image was preprocessed by geometric correction, radiometric calibration, atmospheric correction, and clipping.The MODIS NDVI was a MOD13Q1 product that covered the Sanjiang Plain and provided free of charge on the official NASA website(http://www.nasa.gov/), and its spatial and temporal resolutions were $250 \mathrm{~m}$ and 16 days, respectively. The time range was the growing season of each period (April to October), a total of 104 images, and this study used the 16 days synthetic data of MOD13Q1NDVI products to generate monthly NDVI data through maximum value compositing (MVC). The meteorological data included the temperature and the precipitation data of 33 meteorological stations in and around the Sanjiang Plain from April to October and were provided by the Heilongjiang Meteorological Information Center (Fig. 1). 


\section{Methods}

\section{Interpretation of land use/cover types}

According to the Macro Investigation and

Dynamic Research of the Resource and

Environment[21] and the current land use

characteristics in the study area, the land

use/cover in the study area was classified into

six types, including forest land, cultivated land,

grassland, construction land, water, and

undeveloped land, by using the support vector

machine (SVM) algorithm in the supervised

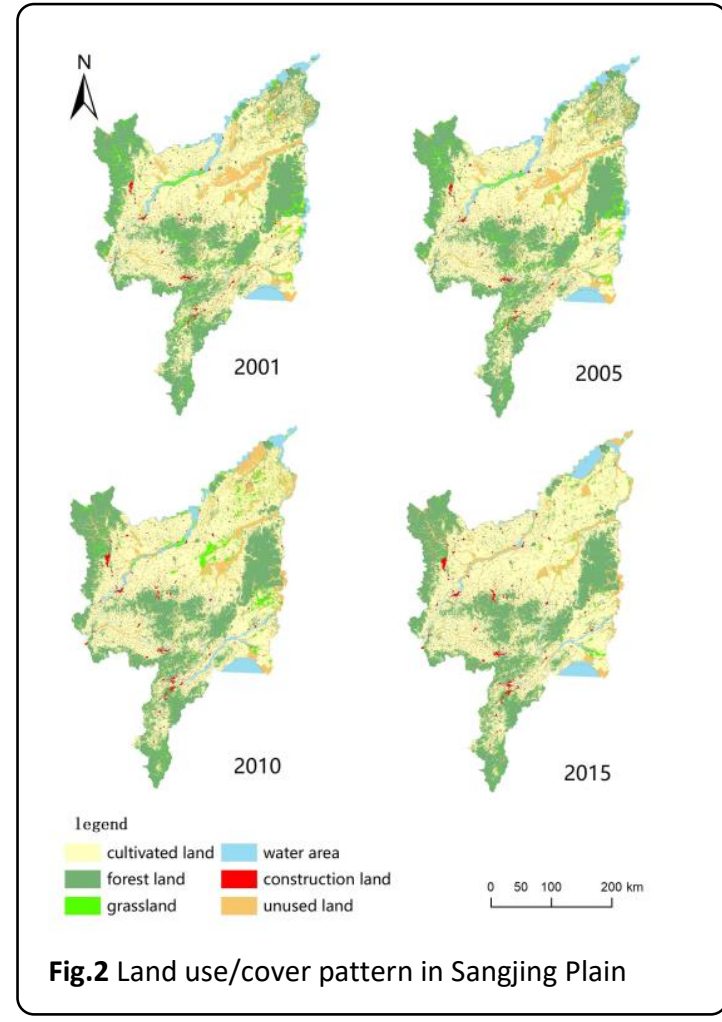

classification method. The spatial distribution

maps of land use/cover types in the study area in 2001, 2005, 2010, and 2015 were obtained (Fig.

2), and the classification results were evaluated on the basis of the field verification points. The

classification accuracy of each type of supervised classification results in the Phase 4 images and

the overall accuracy are over $90 \%$, and the kappa coefficient is above 0.85 , thus indicating that

the accuracy of the classification results meets the research requirements.

\section{Dynamic change characteristics in land use/cover types}

Used the analysis function module of QGIS for statistical and spatial overlay analyses through the interpreted land use/cover status maps of the Sanjiang Plain in 2001, 2005, 2010, and 2015. The land use/cover transfer matrix of Sanjiang Plain in 2001-2015 was obtained. 


\section{Vegetation aboveground biomass model}

The forest land (Formula 1), cultivated land (Formula 2), grassland, and unused land (Formula 3) vegetation biomass models used the research results of Zhao [22], Peng et al. [23], and Li [24]. In accordance with the vegetation biomass model of each land use/cover type and its remotely sensed NDVI data, the grid calculator of QGIS was used to calculate the vegetation biomass $\left(\mathrm{g} / \mathrm{m}^{2}\right)$ of different land use/cover types in each period of the study area. The model was as follows:

$$
\begin{aligned}
& \mathrm{B} 1=5576.245 \times(N D V I)^{2}-6635.377 \times N D V I+2002.202, \\
& \mathrm{~B} 2=87.0518+106.5892 \times N D V I, \\
& \mathrm{~B} 3=2113.575+2125.757 \times N D V I .
\end{aligned}
$$

\section{Estimation of the vegetation carbon storage}

In this paper, the average vegetation carbon storage per $\mathrm{m}^{2}$ (carbon density) was calculated by multiplying the average vegetation biomass per $\mathrm{m}^{2}$ (biomass density) with the conversion coefficient. The total vegetation carbon storage was obtained by multiplying the land use type area.

The model was as follows:

$$
\begin{aligned}
& C_{i}=B_{i} \times O_{i}, \\
& C_{\mathrm{s} i}=C_{i} \times S_{i} .
\end{aligned}
$$

$C_{i}$ is the vegetation carbon density of the $i$ th land use type $\left(\mathrm{g} / \mathrm{m}^{2}\right), B_{i}$ is the vegetation biomass density of the $i$ th land use type $\left(\mathrm{g} / \mathrm{m}^{2}\right)$, and $O_{i}$ is the conversion coefficient between the vegetation biomass and the carbon content of the $i$ th land use type. If the land use type is forest land, $O_{i}$ is 0.5 , and for other land use types, $O_{i}$ is $0.45[25] . C_{\mathrm{si}}$ is the total vegetation carbon storage of the $i$ th land use type $\left(\mathrm{Tg}, 1 \times 10^{12} \mathrm{~g}\right)$, and $S_{i}$ is the total area of the $i$ th land use type $\left(\mathrm{km}^{2}, 1 \times 10^{3} \mathrm{~m}\right)$. 


\section{Related analysis}

This study used a pixel-based correlation analytical method to analyze the response of vegetation carbon storage in the Sanjiang Plain to climate change from 2001 to 2015. The temperature and precipitation data of 33 sites were interpolated with inverse distance weights to obtain meteorological raster data with the same projection and spatial resolution as the carbon storage data by using the QGIS software platform. The carbon storage of areas with unchanged land use type from 2001 to 2015 was extracted. The raster calculator in QGIS was used to calculate the pixel-by-pixel correlation coefficients between vegetation carbon storage and temperature and precipitation in the areas with unchanged land use types. The correlation coefficients between vegetation carbon storage and temperature and precipitation in the areas with unchanged land use types over the 15 years in the growing season of the Sanjiang Plain were calculated. The correlation coefficient formula is as follows:

$$
r_{x y}=\frac{\sum_{i=1}^{n}\left(x_{i}-\bar{x}\right)\left(y_{i}-\bar{y}\right)}{\sqrt{\sum_{i=1}^{n}\left(x_{i}-\bar{x}\right)^{2}} \sqrt{\sum_{i=1}^{n}\left(y_{i}-\bar{y}\right)^{2}}},
$$

where $x_{i}, y_{i}$ is the value of $x, y$ in Year $i, \bar{x}, \bar{y}$ is the annual average of $x, y ; n$ is the number of years; $r_{x y}$ is the correlation coefficient of $x, y$, whose value falls in $[-1,1] ; r_{x y}<0$ indicates a negative correlation, and $r_{x y}>0$ denotes a positive correlation, which means that climate factors promote the increase of vegetation carbon storage, and vice versa.

In the SPSS, the partial correlation analysis was conducted on climate, land use/cover change, and vegetation carbon storage to analyze the correlation between climate and land use/cover change and the main controlling factors of the vegetation carbon storage.The partial correlation coefficient formula is as follows:

$$
r_{x y, z}=\frac{r_{x y}-r_{x y} r_{y z}}{\sqrt{\left(1-r_{x z}^{2}\right)} \sqrt{\left(1-r_{y z}^{2}\right)}}
$$


where $r_{x y}, r_{x z}$, and $r_{y z}$ are the correlation coefficients between $x$ and $y, x$ and $z$, and $y$ and $z$ respectively; $r_{x y, z}$ denotes the partial correlation coefficients between $x$ and $y$ after $z$ is fixed.

\section{Results and analysis}

\section{Response of the vegetation carbon storage to land use/cover changes}

From 2001 to 2015, the land use/cover changes in the Sanjiang Plain were obvious(Fig. 3).The areas of cultimated and construction lands increased overall, The areas of forest land, grassland, water area, and unused land decreased overall. The proportion of cultivated land area increased from $48.24 \%$ to $54.03 \%$, with the area increased by $6292.86 \mathrm{~km}^{2}$. The proportion of construction land area increased from $1.94 \%$ to $2.27 \%$, with the area increased by $357.23 \mathrm{~km}^{2}$. The proportion of forest land area decreased from $33.08 \%$ to $29.96 \%$, with the area decreased by $3389.56 \mathrm{~km}^{2}$. The proportion of grassland area decreased from $3.89 \%$ to $1.92 \%$, with the area decreased by $2141.03 \mathrm{~km}^{2}$.The proportion of water area decreased from $4.79 \%$ to $4.63 \%$, with the area decreased by $173.91 \mathrm{~km}^{2}$. The proportion of undeveloped land area decreased from $8.05 \%$ to $7.18 \%$, with the area decreased by $946.60 \mathrm{~km}^{2}$.

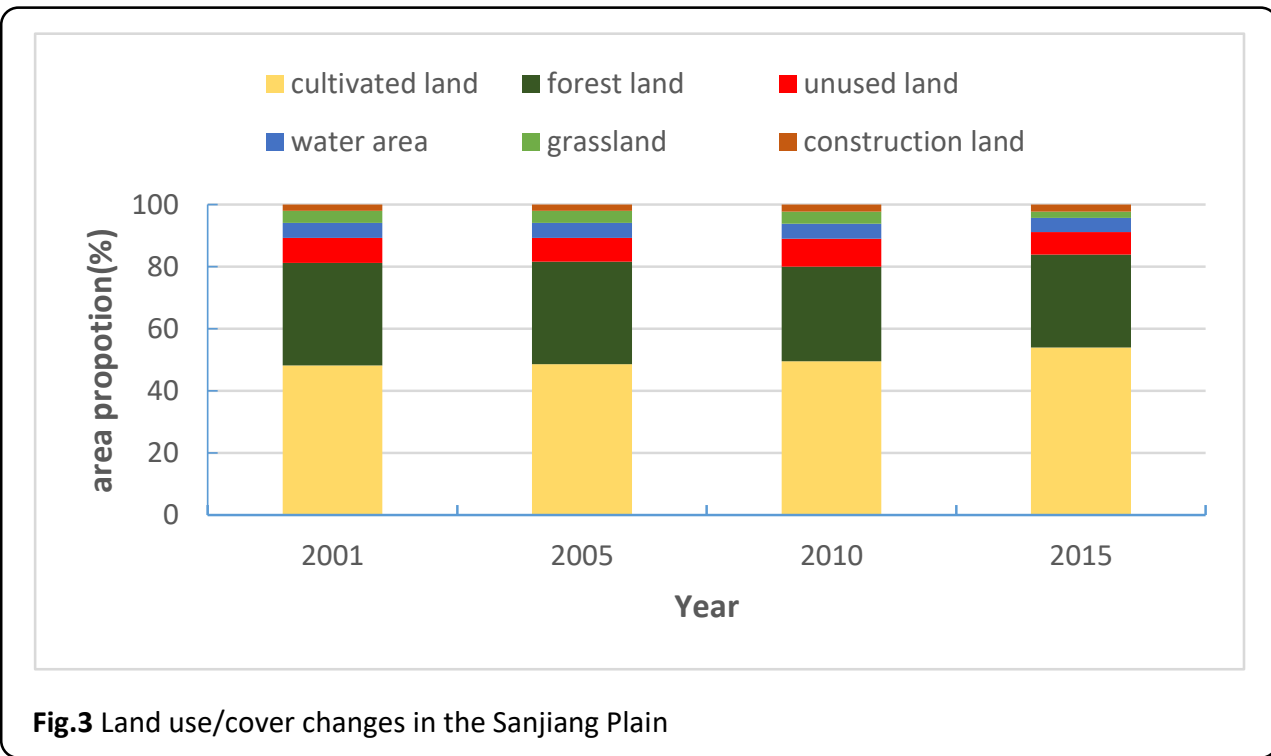


The transfer matrix analysis of the land use/cover data of the Sanjiang Plain in 2001 and 2015 demonstrated that the land use/cover changes mainly occurred in cultivated land, forest land, grassland, and undeveloped land over the 15 years. Cultivated land is the land use type with the largest increase in area, with a total of $4407.5 \mathrm{~km}^{2}$ of forest land, $1218.1 \mathrm{~km}^{2}$ of grassland, 557.8 $\mathrm{km}^{2}$ of water, $507.6 \mathrm{~km}^{2}$ of construction land, and $4393.7 \mathrm{~km}^{2}$ of undeveloped land converted into cultivated land. Cultivate land is the major transferred-in land use/cover type of the above-mentioned types. The percentages of areas with unchanged land use/cover type over the 15 years in cultivate land, forest land, grassland, water, construction land, and undeveloped land are $90.86 \%, 81.15 \%, 8.16 \%, 59.87 \%, 72.31 \%$, and $36.20 \%$, respectively.

Table 1 Statistics of area change for different land use/cover types from 2001 to $2015\left(\mathrm{~km}^{2}\right)$

\begin{tabular}{|c|c|c|c|c|c|c|c|c|}
\hline Area & $\begin{array}{l}\text { cultivate } \\
\text { d land }\end{array}$ & $\begin{array}{l}\text { forest } \\
\text { land }\end{array}$ & grassland & $\begin{array}{l}\text { water } \\
\text { area }\end{array}$ & $\begin{array}{l}\text { construc } \\
\text { tion land }\end{array}$ & $\begin{array}{l}\text { unused } \\
\text { land }\end{array}$ & $\begin{array}{l}2001 \\
\text { total } \\
\text { area } \\
\end{array}$ & $\begin{array}{c}\text { transferr } \\
\text { ed-out } \\
\text { area } \\
\end{array}$ \\
\hline $\begin{array}{l}\text { cultivated } \\
\text { land }\end{array}$ & 47622.8 & 1875.8 & 680.7 & 599.3 & 782.4 & 852.7 & 52413.8 & 4790.9 \\
\hline forest land & 4407.5 & 29167.7 & 573.8 & 583.8 & 74.3 & 1134.7 & 35941.8 & 6774.1 \\
\hline grassland & 1218.1 & 1184.2 & 345.9 & 154.3 & 53.2 & 1267.9 & 4223.6 & 3877.7 \\
\hline water area & 557.8 & 78.9 & 72.3 & 3115.6 & 18.9 & 1360.6 & 5204.0 & 2088.4 \\
\hline $\begin{array}{c}\text { constructio } \\
\mathrm{n} \text { land }\end{array}$ & 507.6 & 36.6 & 12.6 & 7.5 & 1528.0 & 20.8 & 2113.2 & 585.2 \\
\hline unused land & 4393.7 & 209.1 & 397.3 & 569.6 & 13.6 & 3167.7 & 8751.0 & 5583.3 \\
\hline 2015 total & 58707.6 & 32552.3 & 2082.6 & 5030.1 & 2470.4 & 7804.4 & 108647.3 & - \\
\hline $\begin{array}{l}\text { transferred- } \\
\text { in area }\end{array}$ & 11084.8 & 3384.6 & 1736.7 & 1914.5 & 942.4 & 4636.7 & - & - \\
\hline area change & 6293.9 & -3389.5 & -2141.0 & -173.9 & 357.2 & -946.6 & & \\
\hline
\end{tabular}

Note: The transferred-out area of a land use type is the difference between the total area of this land use type in 2001 and the area of land that has not been converted. Meanwhile, the transferred-in area is the difference between the total area of this land use type in 2005 and the area of land that has not been converted. The area change is the difference between the total area in 2015 and that in 2001. The data in bold indicate the area of a certain land use type that did not undergo conversion from 2001 to 2015.

\section{Dynamic changes in the vegetation carbon storage}

This study calculated the average biomass density of cultivated land, forest land, grassland, and undeveloped land in the vegetation growing season in the four time periods in the raster calculator on the basis of the vegetation NDVI data in 2001, 2005, 2010, and 2015, and using Formulas 1, 2, 
and 3. Then, this study calculated the average vegetation carbon density and total carbon storage of each land use type according to models 4 and 5.From the changes in the vegetation carbon density in the study area (Fig. 4), the vegetation carbon densities of cultivated land, grassland, and unused land had no significant change, fluctuated between $0.06-0.07 \mathrm{~kg} / \mathrm{m}^{2}, 0.36-0.41 \mathrm{~kg} / \mathrm{m}^{2}$ and $0.39-0.44 \mathrm{~kg} / \mathrm{m}^{2}$, respectively,but the carbon density of the forest land showed remarkable changes and increased continuously. The lowest and highest carbon densities of the forest land were 4.18 (2001) and $7.65(2015) \mathrm{kg} / \mathrm{m}^{2}$, respectively. The average carbon densities of the vegetation in the Sanjiang Plain in 2001, 2005, 2010, and 2015 were 1.27, 1.39, 1.65, and 2.12 $\mathrm{kg} / \mathrm{m}^{2}$, respectively, which were higher than that of the vegetation in China since $2010\left(1.47 \mathrm{~kg} / \mathrm{m}^{2}\right)$ [14], and showed an upward trend. This result indicated that the biomass accumulation in this area was fast and that the vegetation productivity was higher than that of China。

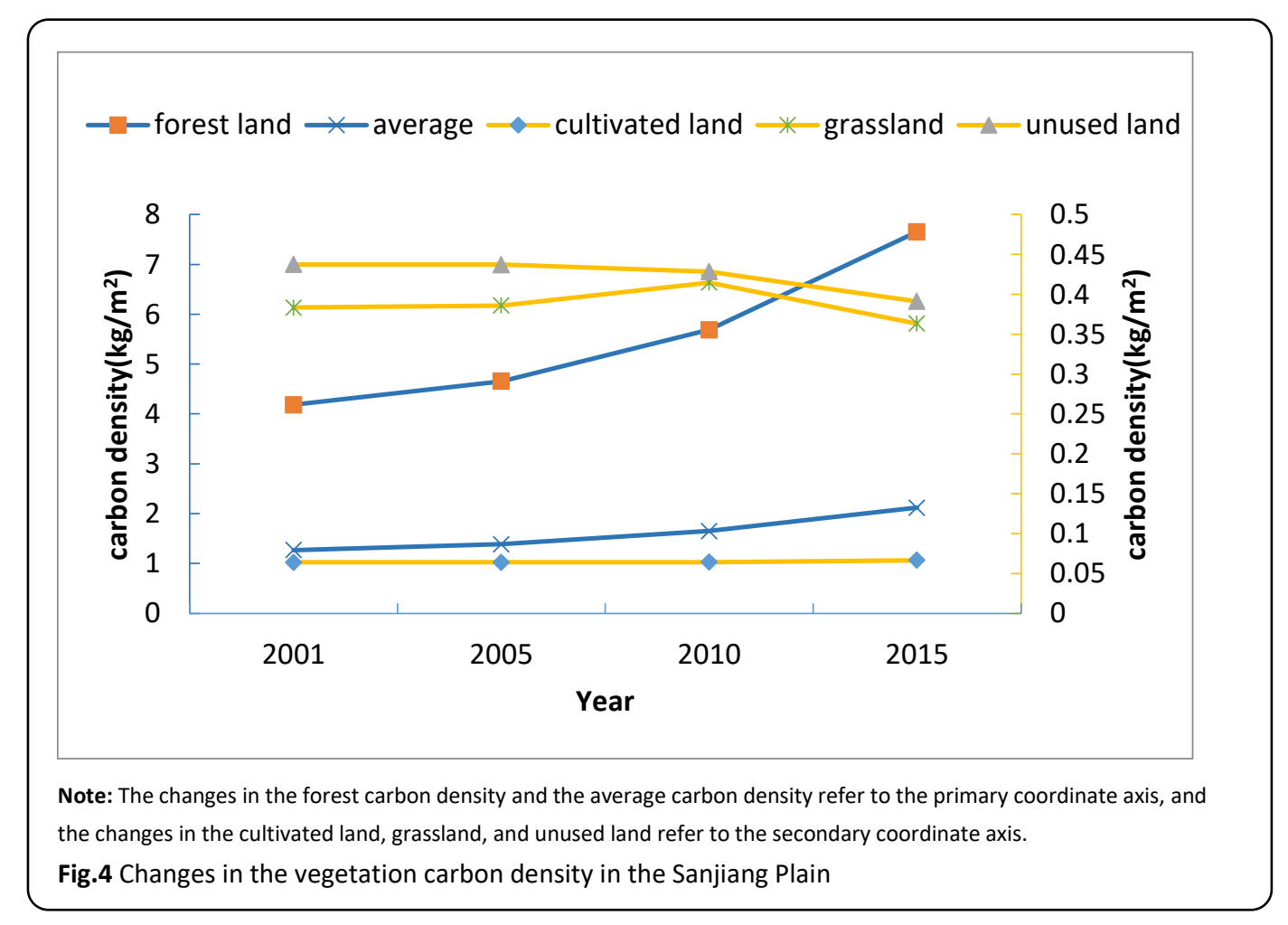

From 2001 to 2015, the vegetation carbon storage of the Sanjiang Plain showed an increasing trend (Fig. 5)., from $159.18 \mathrm{Tg}$ in 2001 to $256.83 \mathrm{Tg}$ in 2015.The carbon storage of forest land 
vegetation significantly increased, from $150.38 \mathrm{Tg}$ in 2001 to $249.11 \mathrm{Tg}$ in 2015 . The carbon storage values of cultivated land also continued to increase, from $3.35 \mathrm{Tg}$ in 2001 to $3.91 \mathrm{Tg}$ in 2015.The carbon storage values of grassland and unused land vegetation The carbon storage values of grassland and unused land vegetation increased overall during 2010-2015 and decreased significantly during 2010-2015, mainly due to significant reductions in grassland and unused land area during this period.From 2001 to 2015, the change in the vegetation carbon storage in the Sanjiang Plain was basically the same as that of the forest land carbon storage, indicating that the forest land carbon storage was the main factor that affected the change in the vegetation carbon storage in the area.

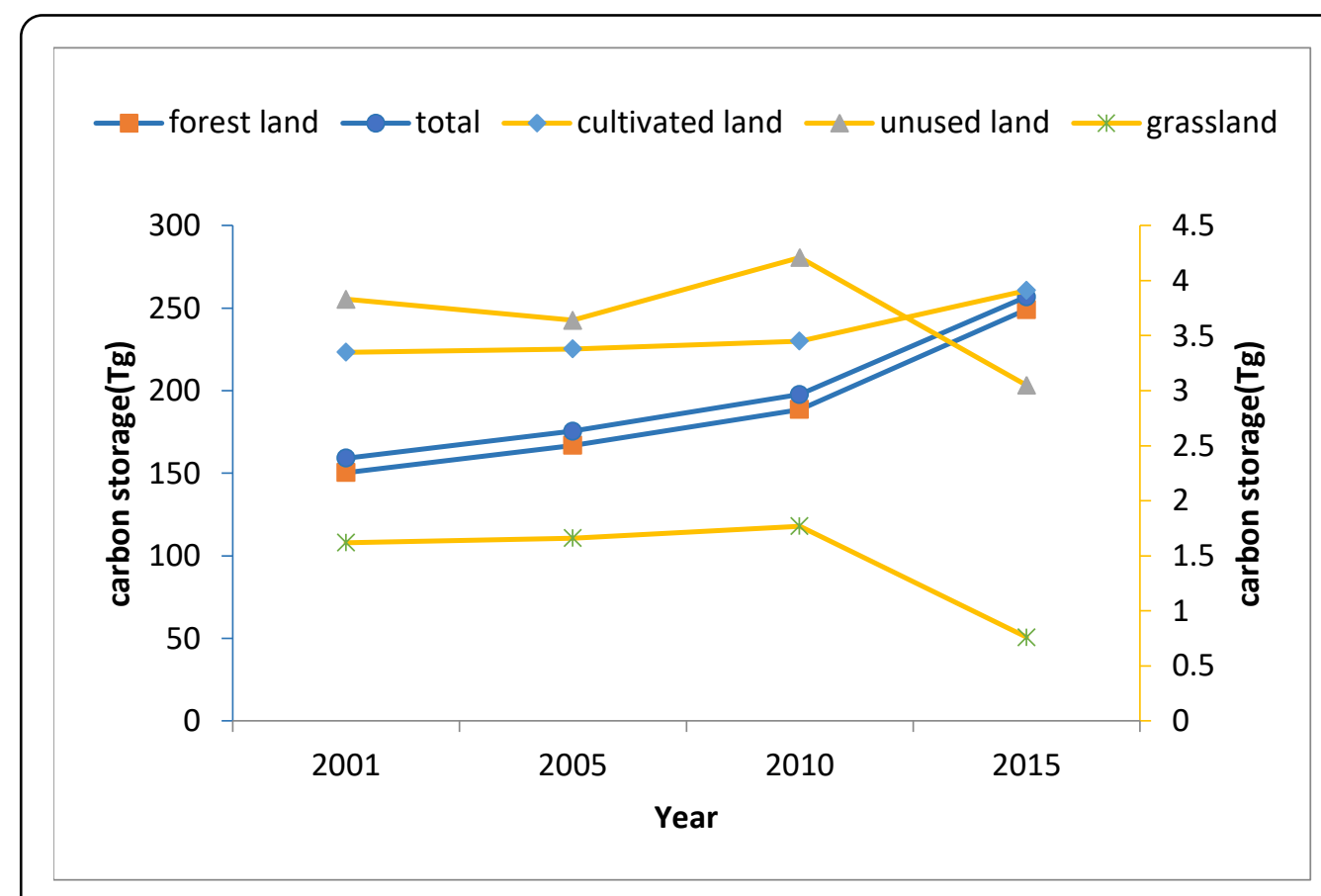

Note: The forest land vegetation carbon storage and total vegetation carbon storage refer to the primary coordinate axis, and the vegetation carbon storage of cultivated land, grassland and unused land refer to the secondary coordinate axis.

Fig. 5 Changes in the vegetation carbon storage in the Sanjiang Plain

\section{Response of vegetation carbon storage to land use/cover change}

According to the mutual conversion area and carbon storage density of cultivated land, forest land, grassland, and undeveloped land, the change in vegetation carbon storage and its net change value 
under each land use/cover change in different time periods from 2001 to 2015 were calculated(Table 2). The land use/cover changes in the three time periods from 2001 to 2015 resulted in the loss of vegetation carbon storage, of which the loss was the largest from 2005 to 2010 , with a loss of $12.15 \mathrm{Tg}$, followed by a loss of $2.78 \mathrm{Tg}$ from 2005 to 2015 . The land use/cover changes in the Sanjiang Plain from 2001 to 2015 resulted in a loss of $22.76 \mathrm{Tg}$ of vegetation carbon storage. Given that the forest land has the highest carbon storage per unit area, the conversion of forest land to cultivated land, grassland, and undeveloped land will lead to a reduction in carbon storage. The total reduction from 2001 to 2015 was $45.86 \mathrm{Tg}$. The conversion of cultivated land, grassland, and undeveloped land to forest land led to an increase in carbon storage, with a total increase of $24.38 \mathrm{Tg}$. The conversion of cultivated land to forest land, grassland, and undeveloped land from 2001 to 2015 led to an increase in carbon storage, with a total increase of $14.71 \mathrm{Tg}$. The conversion of forest land, grassland, and undeveloped land to cultivated land led to a reduction in carbon storage, with a total reduction of $35.22 \mathrm{Tg}$.

Table 2 The change of carbon storage in vegetation in Sanjiang Plain during 2001-2015(Tg)

\begin{tabular}{lcccc}
\hline Conversion of land use and land cover & 2001-2005 & 2005-2010 & 2010-2015 & 2001-2015 \\
\hline cultivated land $\rightarrow$ forest land & 0.26 & 10.52 & 0.82 & 14.23 \\
cultivated land $\rightarrow$ grassland & 0.03 & 0.45 & 0.09 & 0.20 \\
cultivated land $\rightarrow$ unused land & 0.01 & 0.69 & 0.05 & 0.28 \\
forest land $\rightarrow$ cultivated land & -0.57 & -19.69 & -2.29 & -33.44 \\
forest land $\rightarrow$ grassland & -0.17 & -4.01 & -0.19 & -4.18 \\
forest land $\rightarrow$ unused land & -0.03 & -8.07 & -0.02 & -8.24 \\
grassland $\rightarrow$ forest land & -0.02 & -0.32 & -0.71 & -0.36 \\
grassland $\rightarrow$ cultivated land & 0.05 & 6.84 & 0.17 & 8.63 \\
grassland $\rightarrow$ unused land & 0.00 & 0.01 & 0.01 & 0.04 \\
unused land $\rightarrow$ cultivated land & -0.13 & -0.86 & -0.91 & -1.43 \\
unused land $\rightarrow$ forest land & 0.05 & 0.01 & 0.20 & 1.52 \\
unused land $\rightarrow$ grassland & 0.00 & -0.01 & 0.00 & -0.01 \\
net change of carbon storage & -0.53 & -14.46 & -2.78 & -22.76 \\
\hline
\end{tabular}


Although the changes in various land use types in the Sanjiang Plain from 2001 to 2015 led to a loss of vegetation carbon storage, the overall vegetation carbon storage of the Sanjiang Plain during the past 15 years has been increasing(Fig. 6), with an increase of $16.33 \mathrm{Tg}$ from 2001 to 2005, $22.23 \mathrm{Tg}$ from 2005 to 2010, 59.09 Tg from 2010 to 2015, and from 2001 to 2015 a total of 97.65 Tg. The vegetation carbon storage of cultivated land and forest land in the Sanjiang Plain from 2001 to 2015 has been increasing, while the vegetation carbon storage of grassland and undeveloped land has been decreasing. The main reason for the increase in the vegetation carbon storage of cultivated land is the continuous increase of cultivated land area. The $6293.9 \mathrm{~km}^{2}$ increase of cultivated land area over the 15 years result in a $0.56 \mathrm{Tg}$ increase in vegetation carbon storage of cultivated land.During this period, the area of the forest land decreased by $3389.54 \mathrm{~km}^{2}$,

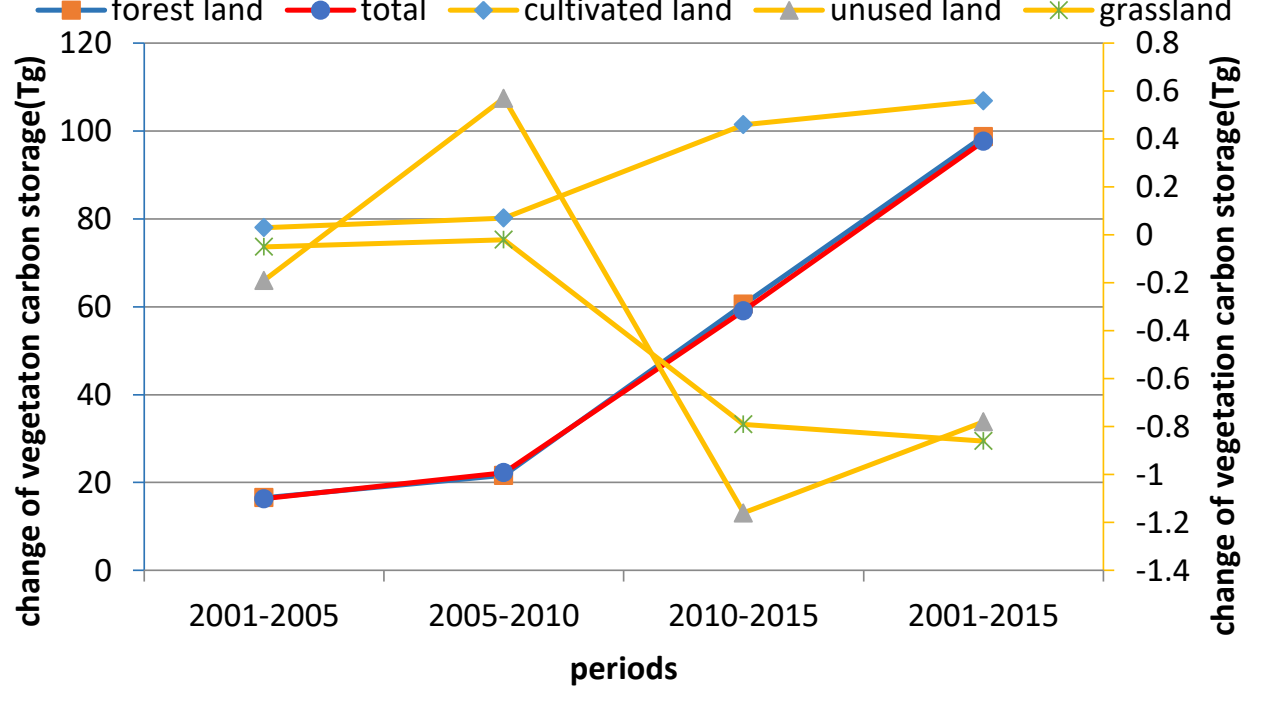

Note: The changes in the forest carbon storage and the total vegetation carbon storage refer to the primary coordinate axis, and the changes in the cultivated land, grassland, and unused land refer to the secondary coordinate axis.

Fig. 6 Changes in the vegetation carbon storage at different time points in the Sanjiang Plain

but the carbon storage of the forest land vegetation increased by $98.73 \mathrm{Tg}$, which was due to the increase in the carbon density of the forest land vegetation especially the continuously substantial increase in carbon density from 2005 to 2015. This increase compensated for the loss of the 
carbon storage caused by the reduction in the forest land area. The grassland area of the Sanjiang Plain was reduced by $2141.03 \mathrm{~km}^{2}$, thereby reducing the vegetation carbon storage of the grassland by $0.86 \mathrm{Tg}$. The area of unused land was also decreased by $946.59 \mathrm{~km}^{2}$, thereby reducing the vegetation carbon storage of unused land by $0.78 \mathrm{Tg}$. In summary, the changes in different land use types and the conversion in vegetation carbon density led to changes in the vegetation carbon storage.

\section{Correlation analysis between the vegetation carbon storage and climate factors}

In the correlation analysis between vegetation carbon storage and climatic factors, in order to eliminate the changes in vegetation carbon storage caused by the mutual conversion of land use types, a pixel-by-pixel correlation analysis was carried out on the vegetation carbon storage and the average temperature and precipitation in the growing season in the areas with unchanged cover types from 2001 to 2015 (Fig. 7) showed that the vegetation pixels with negative correlation between the vegetation carbon storage and the air temperature in the growing season were larger than those with positive correlation as a whole. The average correlation coefficient was negative, and the vegetation pixels positively correlated with precipitation were larger than those negatively correlated with precipitation. The average correlation coefficient was positive (Table 3). This finding showed that the temperature during the growing season inhibited the carbon storage of various vegetations in the Sanjiang Plain and that the precipitation promoted the carbon storage of various vegetations. The reason was that the temperature in the growing season of Sanjiang Plain was higher than that in other months, and the sunshine time was longer, which accelerated the surface evapotranspiration and potentially aggravated the lack of water[25]. If the precipitation did not increase in the same period, the growth of vegetation was limited and would decline the 
vegetation carbon storage. At the same time, the average temperature in the growing season in this area was higher than that in other months, and the vegetation in the growing season was sensitive to precipitation [26]. Thus, the precipitation promoted the growth of vegetation and affected the vegetation carbon storage.

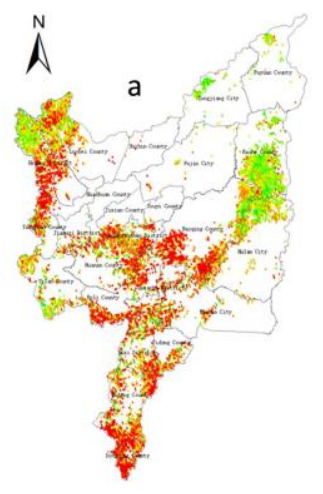

Forest land

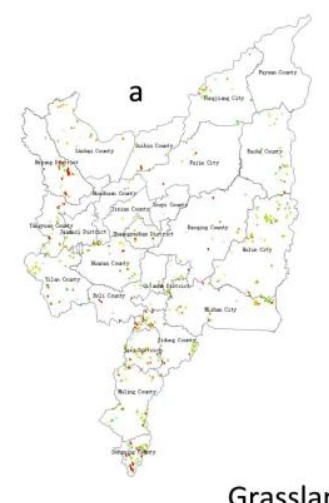

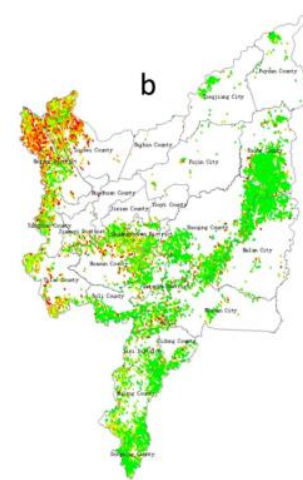

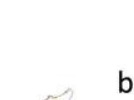

b
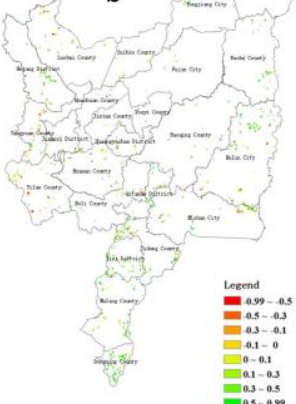
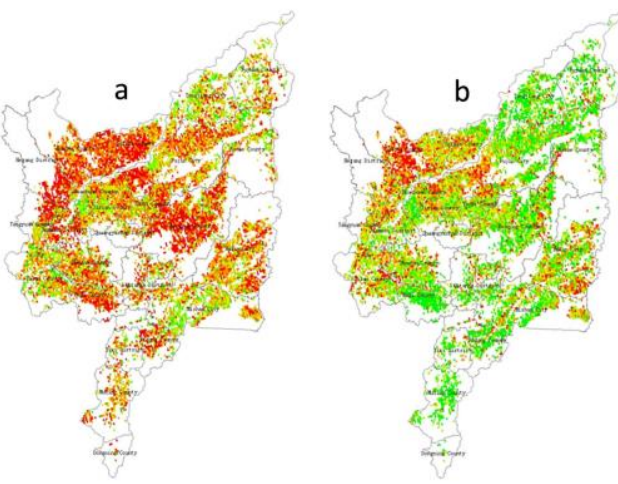

Cultivated land

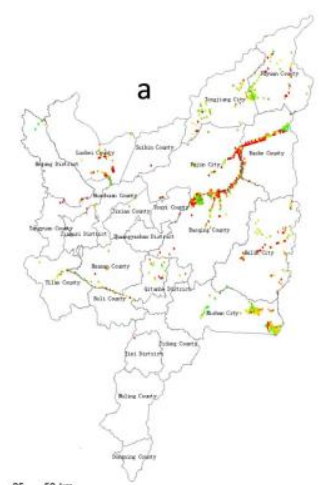

Unused land

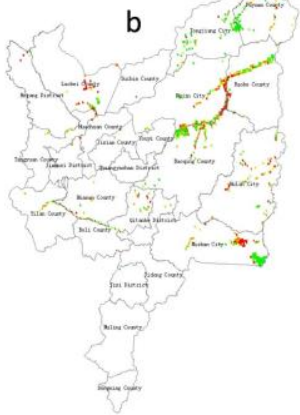

Fig. 7 Distribution of correlation coefficients of the vegetation carbon storage with temperature (a) and precipitation (b) during the growing season in the region with unchanged vegetation type from 2001 to 2015

Table 3 Percentage (\%) and average correlation coefficient of vegetation pixels in the different correlation intervals between carbon storage and climatic factors of each vegetation type in the growing season

\begin{tabular}{|c|c|c|c|c|c|c|c|c|c|c|c|}
\hline \multirow{2}{*}{$\begin{array}{c}\text { Vegetation } \\
\text { Types }\end{array}$} & \multirow{2}{*}{$\begin{array}{l}\text { Number } \\
\text { of pixels }\end{array}$} & \multicolumn{2}{|c|}{$\begin{array}{l}-0.99 \sim-0.5 \\
\text { Percentage }\end{array}$} & \multicolumn{2}{|c|}{$\begin{array}{c}-0.5 \sim 0 \\
\text { Percentage }\end{array}$} & \multicolumn{2}{|c|}{$\begin{array}{c}0 \sim 0.5 \\
\text { Percentage }\end{array}$} & \multicolumn{2}{|c|}{$\begin{array}{c}0.5 \sim 0.99 \\
\text { Percentage }\end{array}$} & \multicolumn{2}{|c|}{$\begin{array}{c}\text { average correlation } \\
\text { coefficient }\end{array}$} \\
\hline & & $\mathbf{T}$ & $\mathbf{P}$ & $\mathbf{T}$ & $\mathbf{P}$ & $\mathbf{T}$ & $\mathbf{P}$ & $\mathbf{T}$ & $\mathbf{P}$ & $\mathbf{T}$ & $\mathbf{P}$ \\
\hline Forest land & 5936 & 25 & 4 & 41 & 19 & 29 & 31 & 4 & 44 & -0.19 & 0.35 \\
\hline $\begin{array}{l}\text { Cultivated } \\
\text { land }\end{array}$ & 9793 & 23 & 8 & 48 & 29 & 25 & 44 & 4 & 24 & -2.00 & 0.15 \\
\hline Grassland & 791 & 22 & 6 & 42 & 23 & 31 & 39 & 4 & 32 & -0.16 & 0.24 \\
\hline $\begin{array}{c}\text { Unused } \\
\text { land }\end{array}$ & 1652 & 25 & 17 & 39 & 29 & 30 & 37 & 6 & 26 & -0.17 & 0.07 \\
\hline
\end{tabular}

Note:T= Average monthly temperature of growing season, $\mathrm{P}=$ Average monthly precipitation in growing season 


\section{Partial correlation analysis of the changes in vegetation carbon storage and climate with}

\section{changes in land use/cover}

From the above analysis, the changes in land use/cover and climate affected the change in the vegetation carbon storage. The partial correlation analysis of the vegetation carbon storage with climate factors (temperature and precipitation) and land use/cover change (area change of land use type)was performed to further determine the main controlling factors. Partial correlation analysis results (Table 4) showed that under constant temperature and precipitation, the grassland vegetation carbon storage and grassland area, cultivated land vegetation carbon storage and cultivated area, and unused vegetation carbon storage and unused land area were significantly correlated (significance level $\leq 0.05$ ). The forest land carbon storage and the forest land area were not significantly correlated (significance level $\geq 0.05$ ). The forest land carbon storage and the forest land carbon density were significantly correlated (significance level $\leq 0.05$ ). In the case of the unchanged vegetation area, the carbon storage of each vegetation was not significantly correlated with temperature and precipitation (significance level $\geq 0.05$ ). This result indicated that the main influencing factor of the vegetation carbon storage changes in grassland, cultivated land, and unused land was the change in the vegetation area and that the main factor of the changes in the forest vegetation carbon storage was the change in the carbon density. Therefore, the changes in the vegetation carbon storage in the growing season of the Sanjiang Plain were determined by the changes in land use/cover and vegetation carbon density. Although temperature and precipitation affected the vegetation carbon storage when only considering climate factors, the partial correlation analysis with land use/cover change showed that climate factors had no 
significant correlation. This finding suggested that the changes in land use/cover and the

vegetation carbon density played a dominant role in the changes in the vegetation carbon storage.

Table 4 Partial correlation analysis of the vegetation carbon storage and the changes in climate and land use/cover during the growing season from 2001 to 2015

\begin{tabular}{|c|c|c|c|}
\hline Control variable & Related variables & $\begin{array}{c}\text { Partial correlation } \\
\text { coefficient }\end{array}$ & $\begin{array}{c}\text { Significance } \\
\text { level }\end{array}$ \\
\hline \multirow{5}{*}{ Temperature } & $\begin{array}{l}\text { Carbon storage of grassland } \\
\text { Area of grassland }\end{array}$ & 0.99 & 0.03 \\
\hline & $\begin{array}{l}\text { Carbon storage of cultivated land } \\
\text { Area of cultivated land }\end{array}$ & 0.99 & 0.01 \\
\hline & $\begin{array}{l}\text { Carbon storage of unused land } \\
\text { Area of unused land }\end{array}$ & 0.95 & 0.05 \\
\hline & $\begin{array}{l}\text { Carbon storage of forest land } \\
\text { Area of of forest land }\end{array}$ & -- & 0.27 \\
\hline & $\begin{array}{l}\text { Carbon storage of forest land } \\
\text { Carbon densities of forest land }\end{array}$ & 0.99 & 0.04 \\
\hline \multirow{5}{*}{ Precipitation } & $\begin{array}{l}\text { Carbon storage of grassland } \\
\text { Area of grassland }\end{array}$ & 0.99 & 0.05 \\
\hline & $\begin{array}{l}\text { Carbon storage of cultivated land } \\
\text { Area of cultivated land }\end{array}$ & 0.99 & 0.02 \\
\hline & $\begin{array}{l}\text { Carbon storage of unused land } \\
\text { Area of unused land }\end{array}$ & 0.95 & 0.05 \\
\hline & $\begin{array}{l}\text { Carbon storage of forest land } \\
\text { Area of of forest land }\end{array}$ & -- & 0.45 \\
\hline & $\begin{array}{l}\text { Carbon storage of forest land } \\
\text { Carbon densities of forest land }\end{array}$ & 0.99 & 0.05 \\
\hline \multirow{4}{*}{$\begin{array}{l}\text { area change of land } \\
\text { use type }\end{array}$} & $\begin{array}{l}\text { Carbon storage of grassland } \\
\text { Temperature }\end{array}$ & -- & 0.25 \\
\hline & $\begin{array}{l}\text { Carbon storage of cultivated land } \\
\text { Temperature }\end{array}$ & -- & 0.14 \\
\hline & $\begin{array}{l}\text { Carbon storage of unused land } \\
\text { Temperature }\end{array}$ & -- & 0.47 \\
\hline & $\begin{array}{l}\text { Carbon storage of forest land } \\
\text { Temperature }\end{array}$ & -- & 0.49 \\
\hline \multirow{4}{*}{$\begin{array}{l}\text { area change of land } \\
\text { use type }\end{array}$} & $\begin{array}{l}\text { Carbon storage of grassland } \\
\text { Precipitation }\end{array}$ & -- & 0.41 \\
\hline & $\begin{array}{l}\text { Carbon storage of cultivated land } \\
\text { Precipitation }\end{array}$ & -- & 0.32 \\
\hline & $\begin{array}{l}\text { Carbon storage of unused land } \\
\text { Precipitation }\end{array}$ & -- & 0.48 \\
\hline & $\begin{array}{l}\text { Carbon storage of forest land } \\
\text { Precipitation }\end{array}$ & -- & 0.38 \\
\hline
\end{tabular}




\section{Discussion}

After decades of reclamation and urbanization in the Sanjiang Plain, the land use/cover has changed significantly. In 2001-2015, the conversion among land use/cover types is frequent and complex. The increase in the areas of cultivated and construction lands, the decrease in the areas of forest land, grassland, and unused land, and land use/cover changes occur in cultivated land, forest land, grassland, and unused land. The vegetation carbon storage of the Sanjiang Plain in 2001-2015 increases continuously (total increase $=97.65 \mathrm{Tg}$ ). Chang Shouzhi et al. [27] have analyzed the effect of land use/cover changes on the vegetation carbon storage in the Sanjiang Plain in 1954-2005 and shown that the land use/cover of the Sanjiang Plain changes significantly in 1954-2005. The cultivated land has increased in a large area, and the taxes on marsh wetland, forest land, and grassland areas are reduced. This finding is generally consistent with the results of this paper. In terms of the changes in the carbon storage of the Sanjiang Plain, the vegetation carbon storage is continuously reduced in 1954-2005, which is contrary to the results of this paper. Reasons include different time scales and large changes in land use/cover types. Moreover, when Chang Shouzhi et al. are calculating the change in the vegetation carbon storage under different land use/cover changes, the carbon storage per unit area of forest land is considered the highest, and the conversion of forest land into other land use/cover types decreases the carbon storage without considering the change in the vegetation carbon density of each land use/cover type. In this paper, the remote sensing data for the four periods from 2001 to 2015 are used. These data consider the changes in the carbon storage caused by the conversion of land use/cover types and the vegetation carbon density caused by factors, such as changes in the vegetation growth. 
Climate and human activities are the main factors affecting the carbon storage of the ecosystem

[4]. This finding is basically consistent with the results of this paper. However, in the partial correlation analysis between the changes in climate and land use, the main controlling factor for the vegetation carbon storage is land use/cover change, and climate factors have no significant effect. The reason may be that the changes in land use types caused by human activities can lead to changes in vegetation within a short time scale, which affect the changes in the vegetation carbon storage in the entire region, but climate change requires a long time scale to affect the vegetation significantly[28]. Therefore, in future studies, the time scale should be extended to further explore the impact of climate change on the carbon storage of the regional vegetation.

\section{Conclusion}

In this paper, the dynamic changes in land use/cover and carbon storage in the Sanjiang Plain from 2001 to 2015 were studied, and the correlation between carbon storage and climatic factors was analyzed to discuss the impact of land use changes on the vegetation carbon storage. The vegetation carbon storage response to changes in land use/cover and climate was analyzed comprehensively. Results showed that in 2001-2015, the cultivated and the construction lands in the Sanjiang Plain continued to increase, and the forest land, grassland, and unused land decreased. In 15 years, the vegetation carbon storage showed an increasing trend. The carbon storage of forest land and cultivated land continued to increase, whereas the carbon storage of grassland and unused land decreased. The vegetation carbon densities of cultivated land, grassland, and unused land did not change significantly, but the carbon density of forest land increased significantly. In 2001-2015, conversion into different land use types and changes in the vegetation carbon density 
directly led to changes in the vegetation carbon storage. The vegetation carbon storage of the Sanjiang Plain was remarkably affected by temperature and precipitation. On a pixel-by-pixel analysis, the carbon storage of various vegetations in the Sanjiang Plain was negatively correlated with the average temperature and positively correlated with the average precipitation. The partial correlation analysis of the changes in climate and land use/cover indicated that the main influencing factor of vegetation carbon storage changes in grassland, cultivated land, and unused land was the change in the vegetation area and that the main factor of the forest vegetation carbon storage changes was the change in the carbon density. Therefore, the changes in the vegetation carbon storage in the growing season of the Sanjiang Plain were determined by the changes in land use/cover and vegetation carbon density. The influence of climate factors was not significant.

\section{Abbreviations}

RS: Remote Sensing

GIS :Geographic Information System

NDVI:Normal Difference Vegetation Index

\section{Acknowledgements}

Not applicable

\section{Authors' contributions}

$\mathrm{HL}$ carried out the overall study design and was a major contributor in writing the manuscript. $\mathrm{CL}$ and $\mathrm{YQ}$ provided support and guidance for this study. XZ and HZ assisted data calculation and processing. LC carried out literature and examination. All authors read and approved the final manuscript.

\section{Funding}

The research is financially supported by the Basic Applicforeion Technology Research Project of Heilongjiang Province (ZNBZ2020ZR06, ZNBZ2018ZR04) and National Natural Science Foundation of China(41971246) 
All data are available on request

\section{Declarations}

\section{Competing interests}

The authors declare that they have no competing interests

\section{Author details}

Harbin Base of International Centre on Space Technologies for Natural and Cultural Heritage under the Auspices of UNESCO(HIST-HB), National and Local Joint laboratory of Wetland and Ecological Consernation, Institute of Natural Resources and Ecology, Heilongjiang Academy of Sciences,Harbin, 150040,China.

\section{References}

1. Caspersen J P, Paeala S W, Jenkins J C, et al. Contributions of land use history to carbon accumulation in U.S. forests.Science, 2000, 290(5494):1148-1151.

2. Lal R. Soil carbon sequestration tomitigate climate change.Geoderma.2004,123:1-22.

3. Jian Ni.Index of vegetation-climate classification and its applications. Chinese Journal of Ecology.1998,17(2):34-44.

4. Guodong Li, Junhua Zhang, Cong Chen, et al. Research progress on carbon storage and flux in different terrestrial ecosystem in China under global climate change.Ecology and Environmental Sciences. 2013,22(5): 873-878.

5. Erfu Dai, Yu Huang, Zhuo Wu,et al.Spatial-temporal features of carbon source-sink and its relationship with climate factors in Inner Mongolia grassland ecosystem.Journal of Geographical Sciences.2016,71(1): 21-34. 6. Jingyun Fang, Guirui Yu, Xiaobo Ren,et al.Carbon sequestration in China's terrestrial ecosystems under climate change-- progress on ecosystem carbon sequestration from the CAS strategic priority research program. Bulletin of Chinese Academy of Sciences.2015, 30(6): 848-857+875.

7. Wenbo Zhu, Jingjing Zhang, Yaoping Cui,et al.Assessment of territorial ecosystem carbon storage based on land use change scenario: A case study in Qihe River Basin. Acta Geographica Sinica. 2019,74(3): 446-459.

8. De Jong B H J, Cairns M A, Haggerty P K, et al. Land-use change and carbon flux between 1970s and 1990s in central highlands of Chiapas, Mexico. Environmental Management. 1999, 23(3): 373-385.

9. Martens D A, Reedy T E, Lewis D T. Soil organic carbon content and composition of 130-year crop, pasture and forest land-use managements. Global Change Biology. 2004,10(1): 65-78.

10. Erb K H. Land use-related changes in aboveground carbon stocks of Austria's terrestrial ecosystems. Ecosystems. 2004, 7(5): 563-572. 
11. Hutyra L R, Yoon B, Alberti M. Terrestrial carbon stocks across a gradient of urbanization: a study of the Seattle WA region. Global Change Biology. 2011, 17(2): 783-797.

12. Jingyun Fang, Anping Chen, Shuqing Zhao,et al.Estimating biomass carbon of China's forests:supplementary notes on report published in science (291: 2320-2322) by fang et al. (2001). Acta Phytoecologica Sinica.2002,26(2):243-249.

13. Jingyun Fang, Zhaodi Guo,Shilong Piao,et al. Terrestrial vegetation carbon sinks in China, 1981-2000. Science in China Series D: Earth Sciences,2007,37(6):804-812.

14. Kerang Li, Shaoqiang Wang, Mingkui Cao.Vegetation and soil carbon storage in China.Science in China Series D: Earth Sciences.2003,33(1):72-80.

15. Xingyu Zhang, Xianjin Huang, Xiaofeng Zhao,et al. Impacts of Land Use Change on the vegetation Carbon storage in the region around Taihu lake.Journal of Natural Resources. 2009(8):1343-1353.

16. Guowei Wu, Yanling Zhao, Yanhua Fu,et al.Impact of reclamation-driven land use change on vegetation carbon store in mining areas.Chinese Journal of Eco-Agriculture. 2015,23(11):1437-1444.

17. Junqia Kong, Rong Yang, Yongzhong Su, et al.Effect of land use and cover change on carbon stock dynamics in a typical desert oasis.Acta Ecologica Sinica.2018,38(21):7801-7812.

18. Panpan Wei, Mei Zan.Changes of Land Coverage and the Impact on Vegetation Carbon Storage in Yili Region.Journal of Northwest Forestry University.2020,35(4):158-166.

19. Tao Zhou, Peijun Shi. Impacts of Land Use Change on Soil Organic Carbon Change in China.Advances in earth science. 2006,21(2):138-143.

20.Jiyuan Liu, Quanqin Shao,Xiaodong Yan ,et al. Geobiophysical effects of land use change on climate change.Chinese Journal of Nature. 2014,36(5): 356-363.

21.Liqiong Zhao.Remote sensing estimation of forest carbon stock in Beijing mountain[Paper]. Beijing Forestry University.2010.

22. Xiao Peng, Shuwen Zhang,.Research on rice growth status based on NDVI and LAI. Remote Sensing Technology and Application. 2002,17(1):12-16.

23. Shuang Li.The renoste sensing estimation and analysis of aboveground biomass of vegetation in Honghe wetland nature reserve[paper].Capital normal university.2009.

24. Caspersen J P, Paeala S W, Jenkins J C, et al. Contributions of land use history to carbon accumulation in U.S. forests. Science. 2000, 290(5494):1148-1151.

25. Guanghua Yang, Anming Bao, Xi Ghen,et al.Study of vegetation cover change and its driving factors over xinjiang during 1998-2007.Journal of glaclology and geocryology.2009,31(3):436-444.

26. Dehua Mao, Zongming Wang, Kaishan Song,et al.The vegetation NDVI variation and its responses to climate change and LUCC from 1982 to 2006 year in northeast permafrost region.China Environmental Science.

2011,31(2):283-292. 
27. Shouzhi Chang, Zongming Wang, Kaishan Song, et al.Impact of land use and land cover change on the vegetation carbon storage in Sanjiang Plain.Ecological Science.2010,29(3):207-214.

28. Shuying Bai, Li Wang,Jianqiao Shi.Time lag effect of NDVI response to climatic change in Yangtze River Basin. Chinese Journal of Agrometeorology.2012,33(4):579-586.

\section{Publisher's Note}

Springer Nature remains neutral with regard to jurisdictional claims in published maps and institutional affiliations.

\section{Rights and permissions}

Open Access This article is licensed under a Creative Commons Attribution 4.0 International License, which permits use, sharing, adaptation, distribution and reproduction in any medium or format, as long as you give appropriate credit to the original author(s) and the source, provide a link to the Creative Commons licence, and indicate if changes were made. The images or other third party material in this article are included in the article's Creative Commons licence, unless indicated otherwise in a credit line to the material. If material is not included in the article's Creative Commons licence and your intended use is not permitted by statutory regulation or exceeds the permitted use, you will need to obtain permission directly from the copyright holder. To view a copy of this licence, visit http://creativecommons.org/licenses/by/4.0/. The Creative Commons Public Domain Dedication waiver (http://creativecommons.org/publicdomain/zero/1.0/) applies to the data made available in this article, unless otherwise stated in a credit line to the data. 
Figures

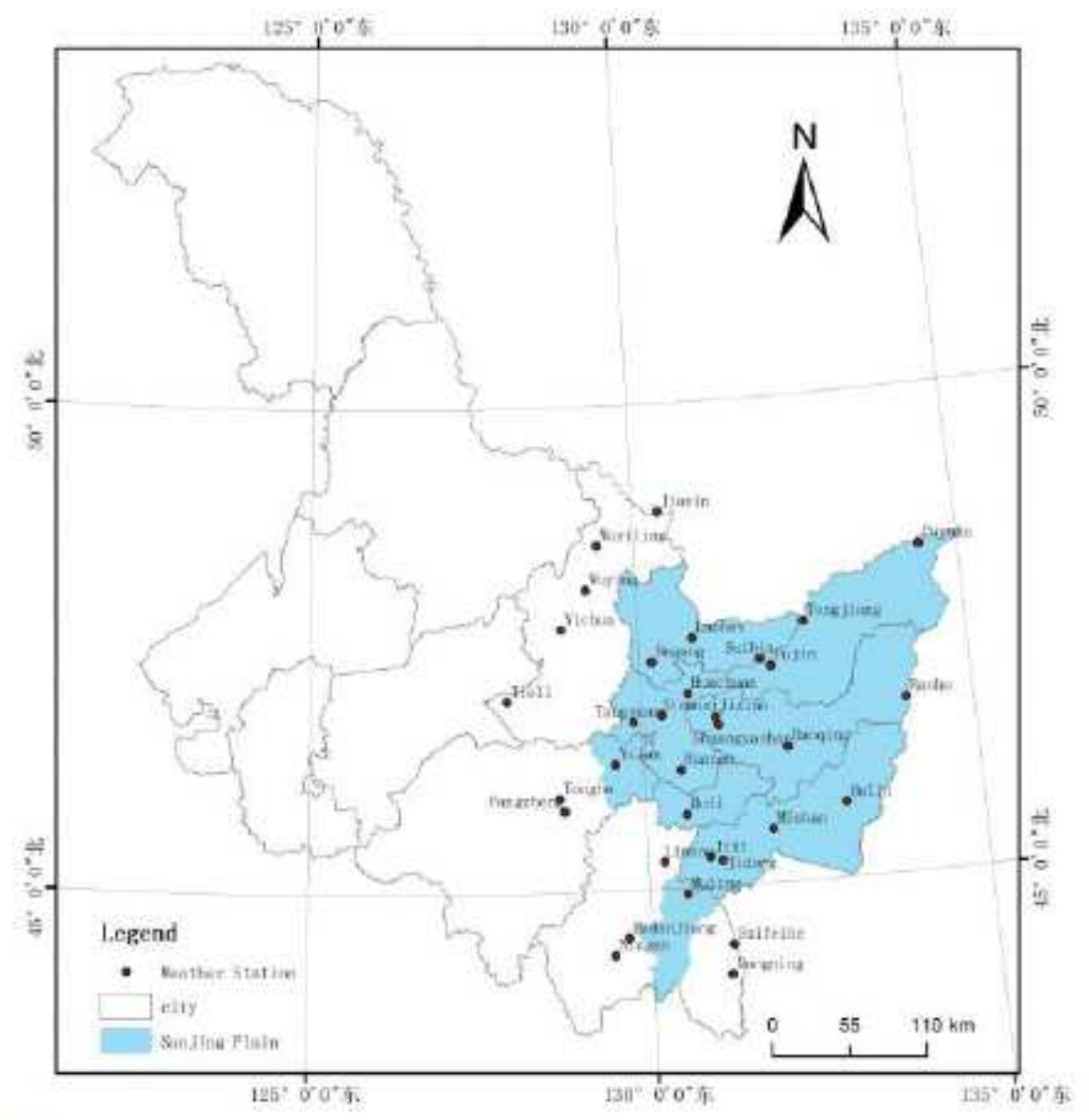

\section{Figure 1}

Geographical location of the Sanjiang Plain and the distribution of meteorological stations Note: The designations employed and the presentation of the material on this map do not imply the expression of any opinion whatsoever on the part of Research Square concerning the legal status of any country, territory, city or area or of its authorities, or concerning the delimitation of its frontiers or boundaries. This map has been provided by the authors. 

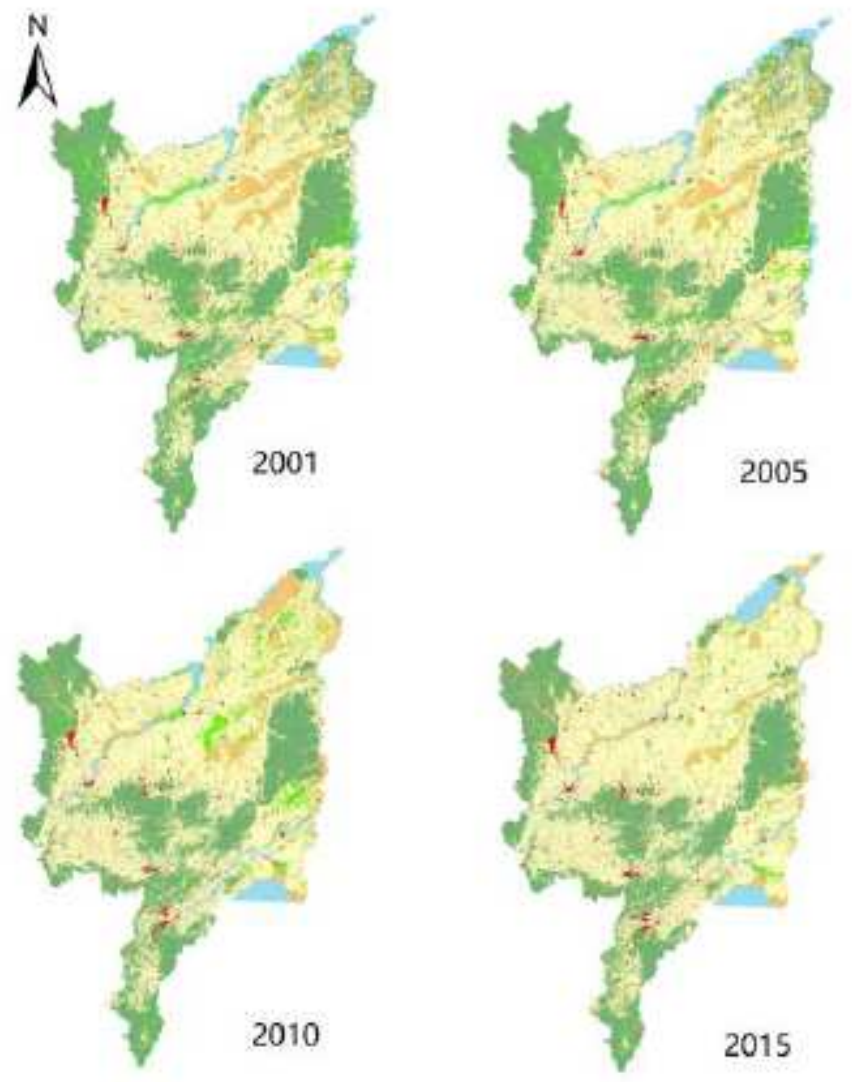

logend

cultivated land 1 watl water area

forest land construction land

grassland unused land

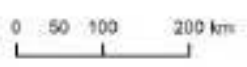

\section{Figure 2}

Land use/cover pattern in Sangjing Plain Note: The designations employed and the presentation of the material on this map do not imply the expression of any opinion whatsoever on the part of Research Square concerning the legal status of any country, territory, city or area or of its authorities, or concerning the delimitation of its frontiers or boundaries. This map has been provided by the authors. 


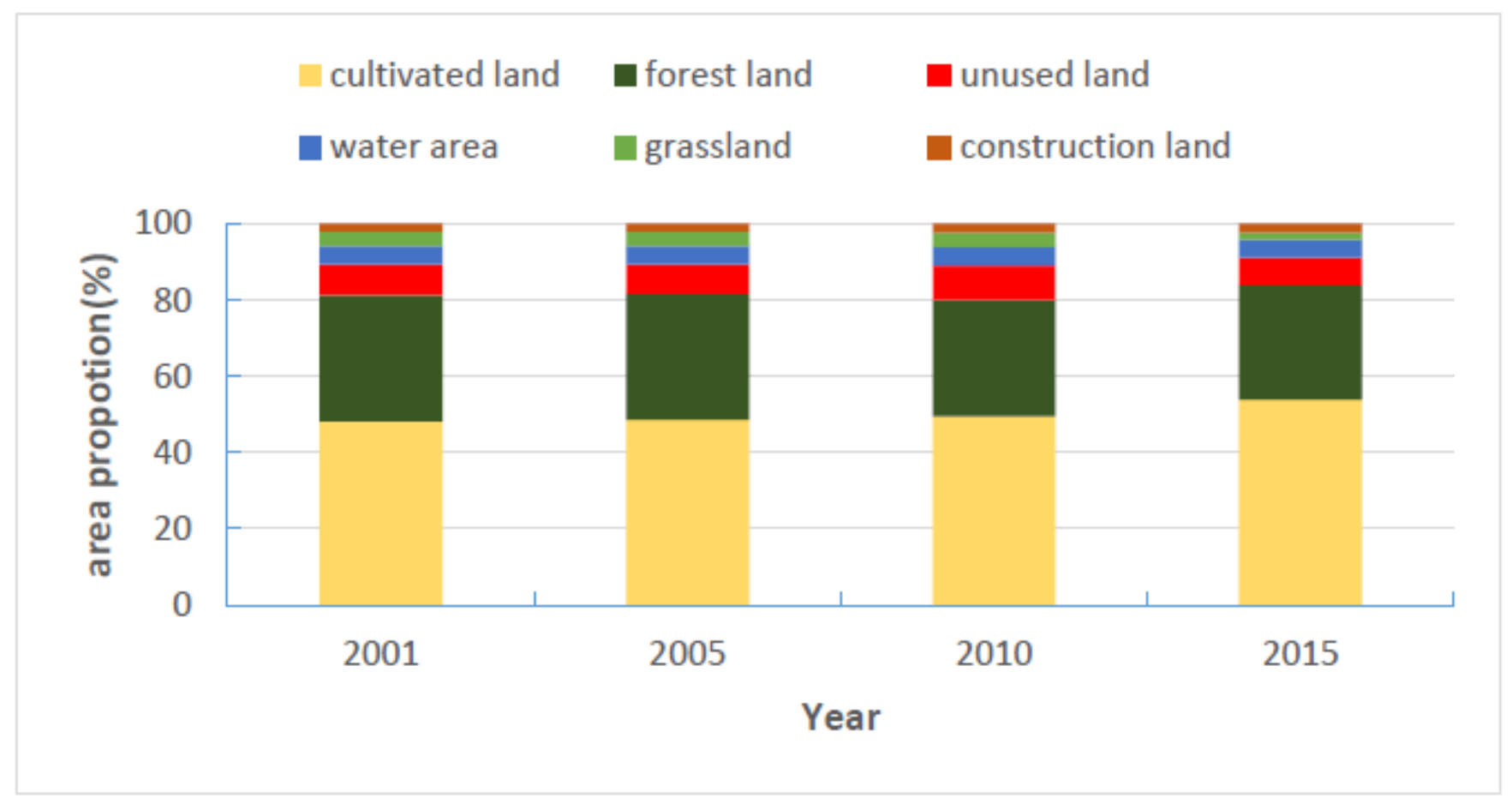

Figure 3

Land use/cover changes in the Sanjiang Plain

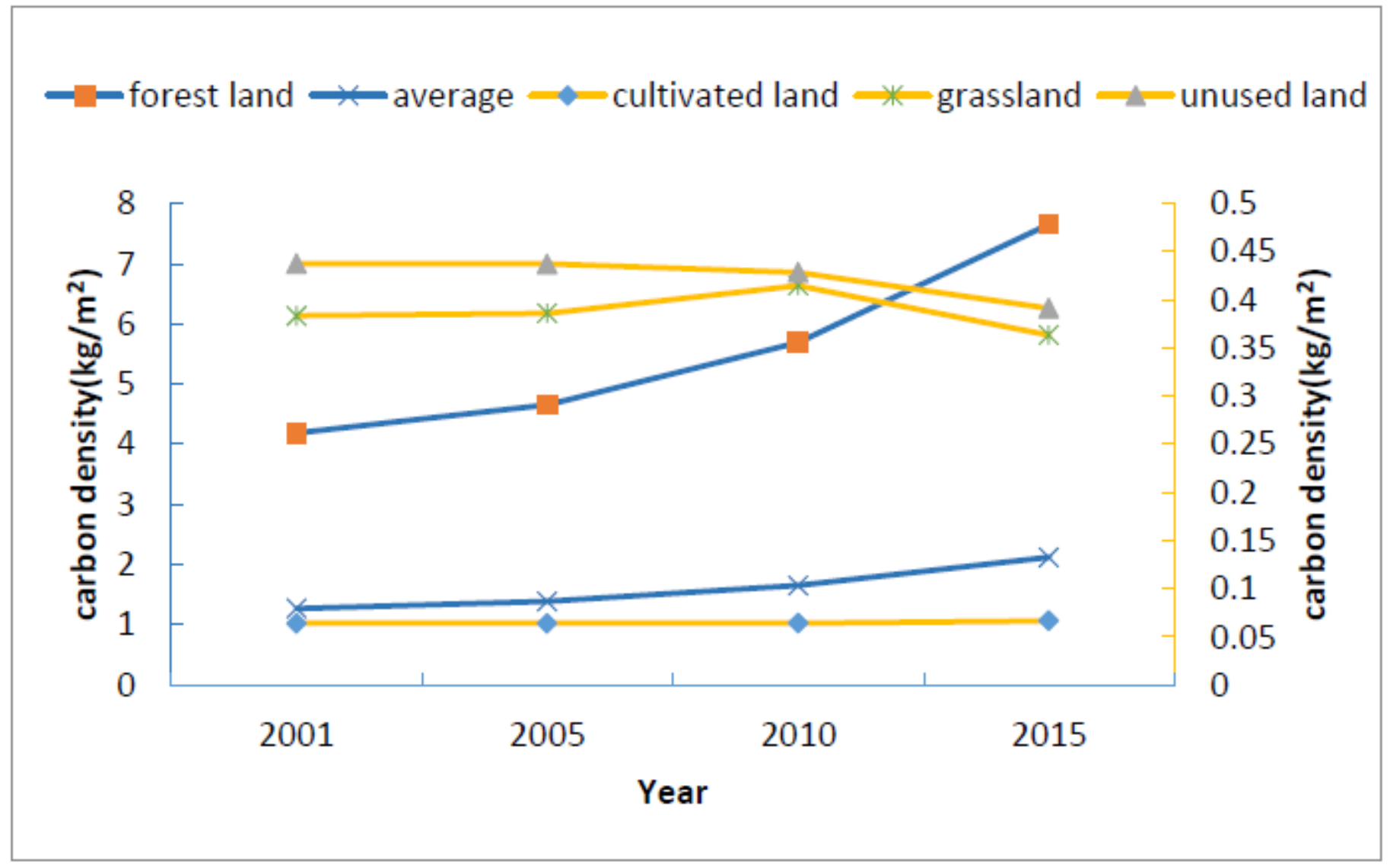

Figure 4 
Note: The changes in the forest carbon density and the average carbon density refer to the primary coordinate axis, and the changes in the cultivated land, grassland, and unused land refer to the secondary coordinate axis. Changes in the vegetation carbon density in the Sanjiang Plain

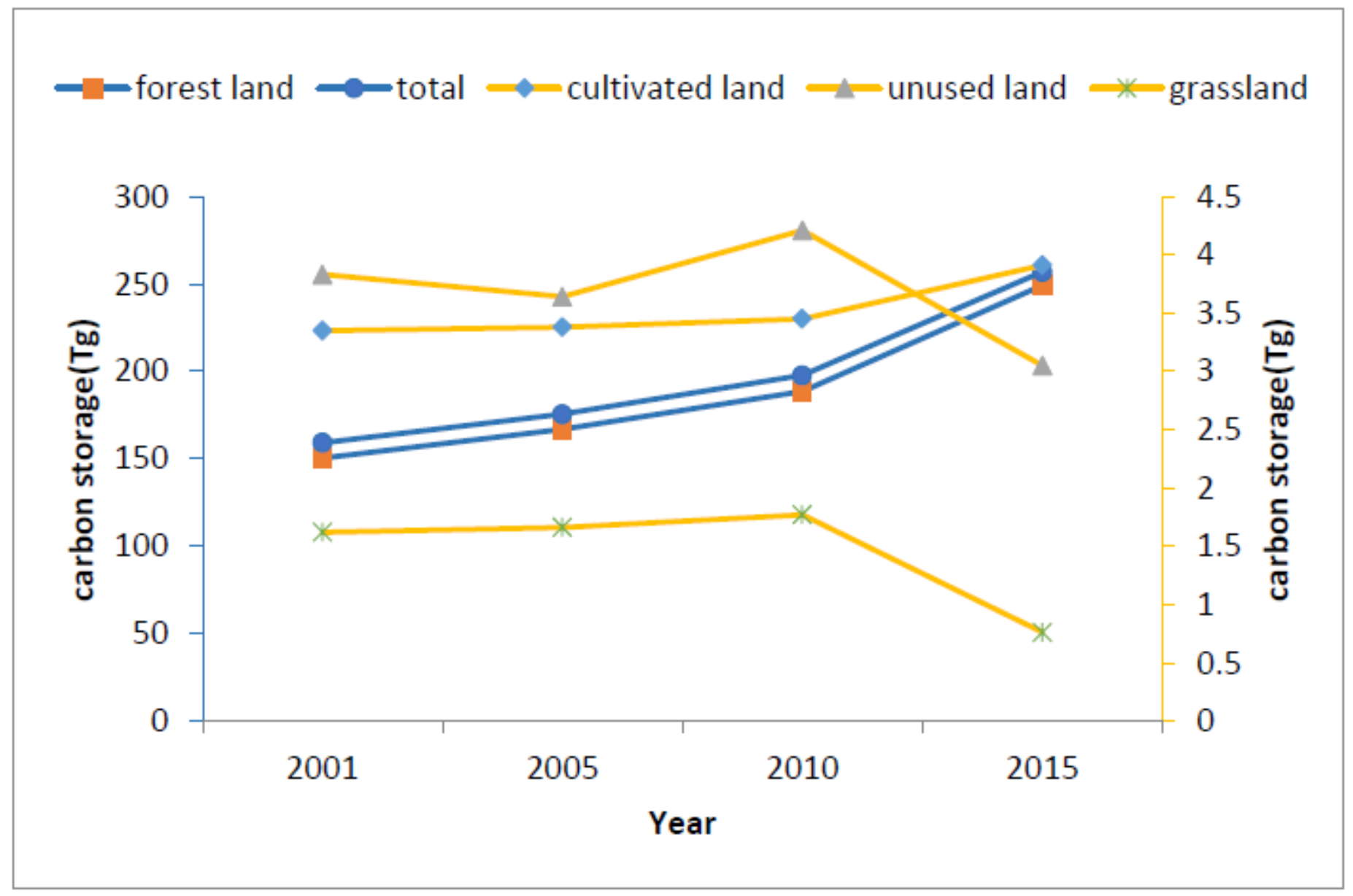

\section{Figure 5}

Note: The forest land vegetation carbon storage and total vegetation carbon storage refer to the primary coordinate axis, and the vegetation carbon storage of cultivated land, grassland and unused land refer to the secondary coordinate axis. Changes in the vegetation carbon storage in the Sanjiang Plain 


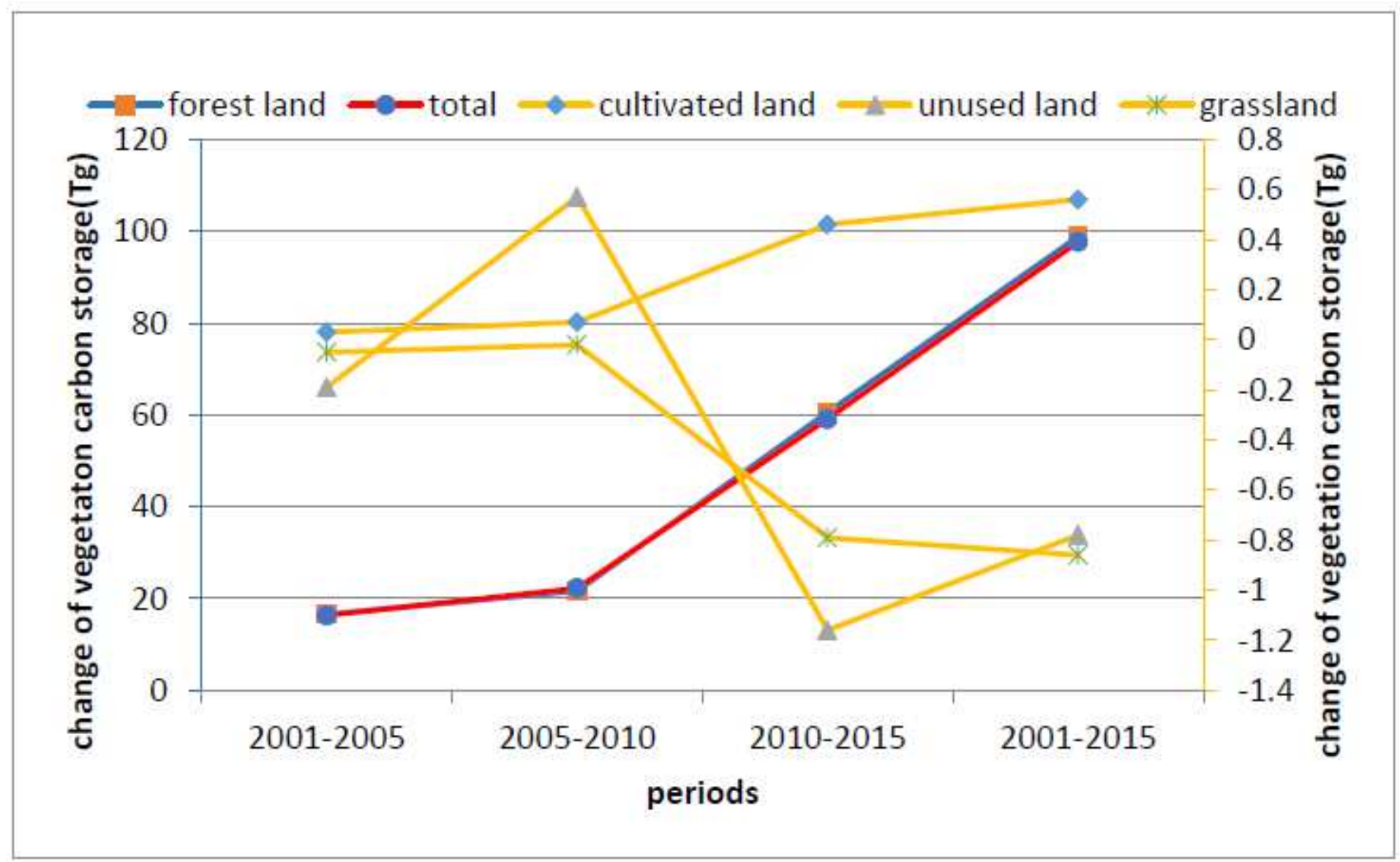

\section{Figure 6}

Note: The changes in the forest carbon storage and the total vegetation carbon storage refer to the primary coordinate axis, and the changes in the cultivated land, grassland, and unused land refer to the secondary coordinate axis. Changes in the vegetation carbon storage at different time points in the Sanjiang Plain 


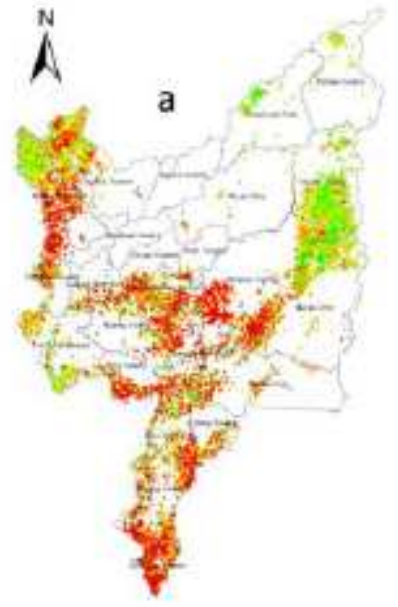

Forest land

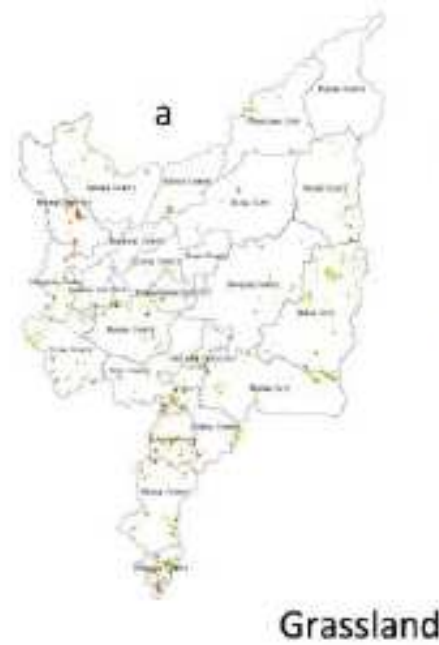

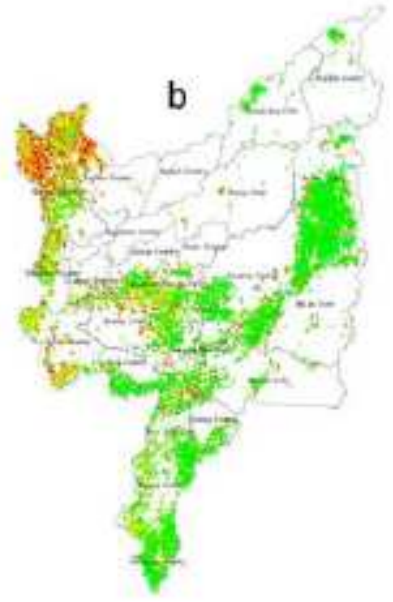

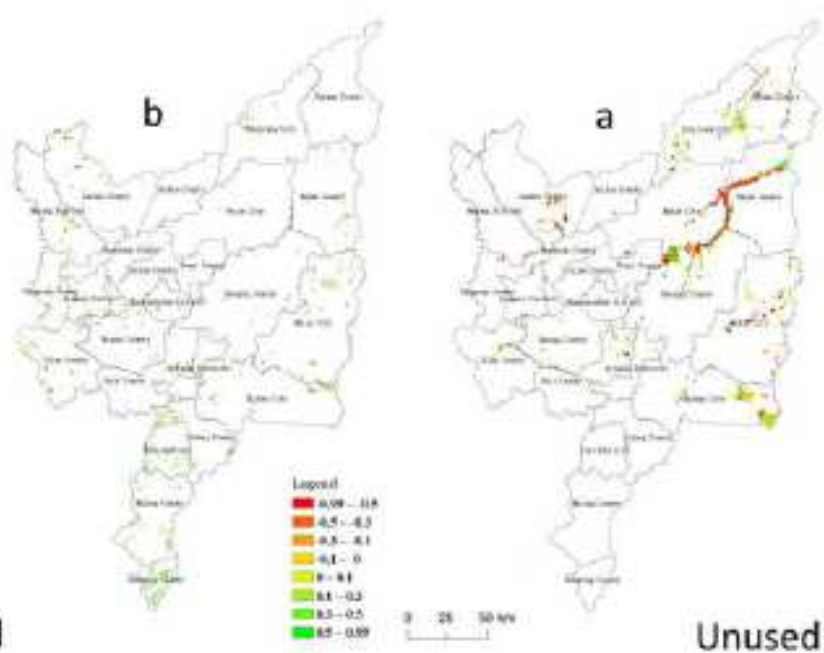

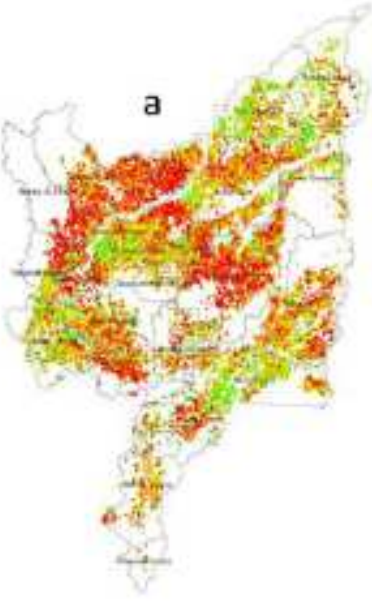

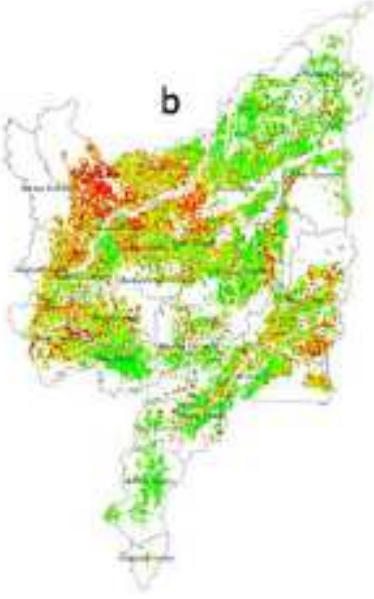

Cultivated land

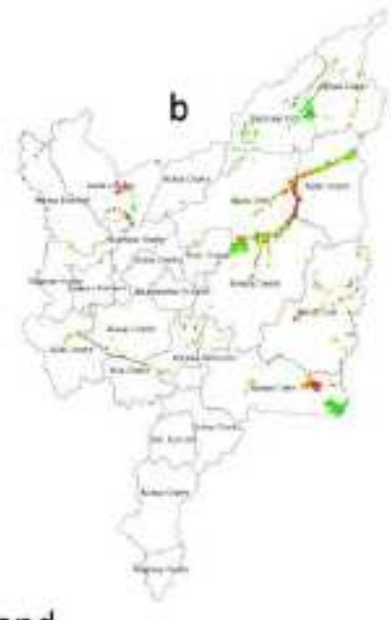

Figure 7

Distribution of correlation coefficients of the vegetation carbon storage with temperature (a) and precipitation (b) during the growing season in the region with unchanged vegetation type from 2001 to 2015 Note: The designations employed and the presentation of the material on this map do not imply the expression of any opinion whatsoever on the part of Research Square concerning the legal status of any country, territory, city or area or of its authorities, or concerning the delimitation of its frontiers or boundaries. This map has been provided by the authors. 